\title{
Science of Balance Preparation: Substance and Stages of Development in Russia
}

\author{
Kulikova L.I. \\ Goshunova A.V.
}

Kazan Federal University, Institute of Management, Economics and Finance, Kazan, 420008, Russia

\section{Doi:10.5901/mjss.2014.v5n24p49}

\section{Abstract}

In this article we have studied the stages of the historical development and formation of science of balance sheet preparation. The article considers various approaches to the essence of keeping a balance sheet as well as its content in the investigations of Russian scientists of the end of the XIX the beginning of XX century. The article demonstrates how the economic essence and content of balance sheet preparation have changed during the development of accounting sciences; different kinds of accounting knowledge can be pointed out - "accounting", "keeping accounts", "bookkeeping" and "science of balance preparation".

Keywords: science of balance preparation, bookkeeping, keeping accounts, accounting

\section{Introduction}

The science of balance preparation in Russia was created at the end of XIX - the beginning of XX century. During the years authors had different understanding of the concept of this science (Sievers, 1892; Galagan, 1928; Galperin, 1930; Rudanovskiy, 1928; Weizmann, 1924; Blatov, 1931; Kiparisov, 1928; Koshkin, 1933).

Very often "science of balance preparation" was interpreted as "keeping accounts". At the same time according to many authors, the "keeping accounts" should be distinguished from the definition "bookkeeping". In the 1892 a prominent Russian accountant Sievers, 1892 in his book "Keeping accounts and bookkeeping. The research experience" has defined bookkeeping as practical activity and "keeping accounts" as science about accounting (Sievers, 1892). According to his opinion, the words "keeping accounts", "accounting" and "bookkeeping" are synonymous. Sievers, 1892 has stressed that "keeping accounts" was a purely Russian word which was corresponding to French word "comptabilite", "accounting" was Russian word for German word "Buchhalterei", and "bookkeeping" was Russian word formed from the direct translation of French "tenue des livres" and German "Buchfuhrung". On the base of etymological analysis of these words we can see that "keeping accounts" expresses management of accounts, while "accounting" and "bookkeeping" highlight keeping of the books.

In the twenties of the XX century definition of "keeping accounts" is fixed in the accounting theory as science.

\section{Materials and Methods}

In order to investigate the process of development of balance preparation science, archive books and materials have been studied in detail. All collected definitions were analyzed and classified.

\section{Results and Discussion}

Professor Galagan (Galagan, 1928) in the 1928 in his book "Foundations of general keeping accounts" has noted that in countable sciences it was possible and necessary to distinguish theoretical side of science from the practice. According to his opinion, "a set of fundamental propositions explaining some practical techniques represents a theoretical science, which is called keeping accounts; a set of practices developed by keeping accounts and applied in practice is known as bookkeeping or accounting". Galagan, 1928 has supposed that keeping accounts was a science because it used the same methods which were generally accepted in the scientific disciplines.

Professor Galperin,1930 in the 1930 in his book "Essays on the theory of balance" has considered that it was necessary to make difference between the concept of "accounting", "keeping accounts" and "science of balance 
preparation". According to his opinion, "accounting is the first stage of our science (Galperin, 1930). Being limited mostly by techniques of registration of business facts, accounting was more an art than a science. Keeping accounts represents a further development of accounting. At this stage the art of accounting is becoming a science of accounting, which is not limited by registration of business operations, but extends to the research of accounts' functions and principles which determine various techniques of registration". As Galperin, 1930 has considered, "our science is reaching the greatest scientific heights and the peak of creative cognition when it becomes a science of balance preparation - the science of balance sheet". Thus, Galperin (Galperin, 1930) has put forward the idea that science of balance preparation represented a new stage in the development of the accounting knowledge.

Professor Rudanovskiy, 1928 which was named by Galperin, 1930 as outstanding researcher, founder of science of balance preparation, in the 1928 in his book "The Theory of the balance sheet accounting. Introduction to a balance sheet accounting. Balance sheet as an object of accounting" has written that science of balance preparation was a special science, which had a balance sheet as its object (Rudanovskiy, 1928). The purpose of this science is an assessment of all business activities. Rudanovskiy, 1928 has given the following definition: "Science of balance preparation is a special science, which, firstly, gives the knowledge of total economic relationships opened by this science in business economy and which is called balance. Secondly, this science gives the theory as a particular set of balance calculation methods, which makes up the accounting, and, finally, for practical purposes, this science is called to answer the question about assessment of total economic activities, which are a part of scientific object - balance sheet.

According to another well-known scientist Weizmann, 1924 science of balance preparation is a part of bookkeeping. Weizmann, 1924 has considered that "using the opportunities offered by bookkeeping, the person who studies the life of enterprise, can not only give an overview of company's property and achieved results, but also is able to assess its financial stability" (Weizmann, 1924). According to Weizmann, 1924 bookkeeping is divided into four parts: keeping accounts, science of balance preparation, accounting expertise (or auditing) and accounting analysis. He has suggested that science of balance preparation was the prelude to the analysis of the balance sheet (Weizmann, 1924). Thus, Weizmann, 1924 has distinguished science of balance preparation and balance sheet analysis.

Some authors have considered that keeping accounts and science of balance preparation were two different but equal sciences. This approach was adopted primarily by Blatov, 1931, the author of many academic and practical tutorials on science of balance preparation. He has supposed that the purpose of keeping accounts was construction of balance sheet and the purpose of science of balance preparation was study of balance sheets (Blatov, 1931). Science of balance preparation represents a natural continuation and logical finish of keeping accounts. According to Blatov, 1931, science of balance preparation is a new, independent branch of accounting knowledge, which is necessary for a systematic and comprehensive, theoretical and practical, general and special study of balance sheets (Blatov, 1931). Thus, Blatov, 1931 has considered science of balance preparation as analysis of balance sheet.

Blatov, 1931 has supposed that science of balance preparation should investigate balance from two points of view: from the formal point of view and according to its content. The study of balance sheet from a formal point of view was named by Blatov, 1931 as countable analysis, and the study of the balance content - economic analysis (Blatov, 1931).

Kiparisov, 1928 in 1928 in the book "Foundations of science of balance preparation. The construction and analysis of balance sheets" has supposed that keeping accounts was divided into three parts: science of balance preparation, history of keeping accounts and general theory of accounting. Moreover, he has pointed out two parts of science of balance preparation: first part dealt with the doctrine of the balance construction and second part focused on the doctrine of methods of researching economic activity of business unit on the base of its balance sheet (Kiparisov, 1928).

Like Blatov, 1931, Kiparisov, 1928 has subdivided science of balance preparation into general and special parts. However, in contrast to Blatov, 1931, Kiparisov, 1928 has considered science of balance preparation more widely, not only as analysis, but also as construction of balance sheet (Kiparisov, 1928).

Koshkin, 1933 in 1933 in his book "On the methods of operational-balance accounting" has presented science of balance preparation as a part of counting science, which differed from keeping accounts. He has written: "in recent years instead of definitions "keeping accounts" and "bookkeeping" accounting was used to be called as science of balance preparation and more often as balance accounting" (Koshkin, 1933).

Koshkin, 1933 has believed that theory of accounting and counting analysis were necessary to be distinguished from keeping accounts. Author also has suggested that science of balance preparation consisted of theory of balance sheet and its economic analysis (Koshkin, 1933). The theory of balance sheet includes a description of balance, its methodology, methods and classification of balance sheet items. According to Koshkin, 1933 the balance is a method of current accounting. Moreover he has noted three stages of development of the balance accounting: calculation, materiality and balance. 


\section{Conclusion}

Very often "science of balance preparation" was interpreted as "keeping accounts". At the same time according to many authors, the "keeping accounts" should be distinguished from the definition "bookkeeping".

In the twenties of the XX century definition of "keeping accounts" is fixed in the accounting theory as independent science.

Being limited mostly by techniques of registration of business facts, accounting was more an art than a science. Keeping accounts became next stage of further development of accounting.

Some famous Russian scientists have expressed the view that accounting science was reaching the greatest scientific heights and the peak of creative cognition when it became a science of balance preparation - the science of balance sheet.

In such conditions science of balance preparation represented a new stage in the development of the accounting knowledge.

Thus, the economic substance and content of science of balance preparation have been changed during the development of accounting knowledge and economic analysis.

\section{References}

Sievers E.E., 1892. Keeping accounts and bookkeeping. The research experience, General stock in the bookstore of N.G. Martynov, Russia. pp: 69.

Galagan A.M., 1928. Foundations of general keeping accounts, Publishing House of People's commissariat of USSR and RSFSR, Russia. pp: 229.

Galperin Y.M., 1930. Essays on the theory of balance, Publication of public courses on industrial-economic sciences and the administrative machinery. Tiflis, Russia. pp: 278.

Rudanovskiy A.P., 1928. The theory of the balance sheet accounting. Introduction to a balance sheet accounting. Balance sheet as an object of accounting,Makiz, Russia. pp: 183.

Weizmann N.R., 1924. Accounting analysis. Methods of study of commercial enterprise on the base of its accounting, Typography named Artem, Russia. pp:56.

Blatov N.A., 1931. Science of balance preparation (general course), State Trade Publishing House, Russia. pp: 296.

Kiparisov N.A., 1928. Foundations of science of balance preparation. The construction and analysis of balance sheets, Publishing House of People's commissariat of USSR and RSFSR, Russia. pp: 223.

Koshkin I.A., 1933. On the methods of operational-balance accounting, Leningrad Regional Publishing House, Russia. pp: 286.

Seidel, G. (1977)/ Assessment and evaluation of fixed capital and floating assets in preparation for the opening balance sheet/ Krankenhaus Umschau, 46 (7), pp. 567-572.

Gláserová, J. (2010). Accounting methodical approaches of business entities in comparisson to bank accounting and to insurance company accounting in the Czech Republic. Acta Universitatis Agriculturae et Silviculturae Mendelianae Brunensis, 58 (6 PART 1), pp. 133-142.

James, M.L. (2009). Accounting for pensions and other postretirement benefit plans and the use of accounting estimates and changes in estimates: An ethical perspective. Journal of the International Academy for Case Studies, 15 (1), pp. 39-48.

Goldsmith, T. (2002). Resources and Reserves - Their Impact on Financial Reporting, Valuations and the Expectations Gap. Australasian Institute of Mining and Metallurgy Publication Series, (3), pp. 21-25. 